\title{
EMERGING CONSTITUTIONALISM IN THE PEOPLE'S REPUBLIC OF CHINA
}

The aim of the paper is to present the process of evolving of the constitutionalism in People's Republic of China. The first, introductory part briefly provides the content of the Chinese Constitution. The second part discusses the latest amendments to the Constitution and its significance. The third part is dedicated to the case study regarding application of the constitutional provisions and the mechanism of reviewing them. In the fourth paragraph, the possible future steps in development of constitutionalism was indicated. The last paragraph is dedicated to the summary.

\section{Constitution of the People's Republic of China - the basics}

The word constitution - 宪法 (xiànfă) was imported from Japan. The word xiàn did in fact existed in classical Chinese - it meant 'law, order, or edicts' and had some normative implications. But it did not mean the constitution in modern sense, in the sense of laying out of government structure and the protection of individual rights. ${ }^{1}$

Since Aristotle, many western thinkers such as Grotius, Spinoza, Hobbes, Locke, Rousseau, and Montesquieu, have contributed to the notion of the rule of law. The most explicit explanation of the concept was given by Albert van Dicey - rule of law: means first of all the absolute supremacy or predominance of regular law as opposed to the influence of arbitrary power, or even of wide discretionary authority on the part of government, second it also means the equal subjection of all classes to the ordinary law of the land administered by the ordinary law courts. ${ }^{2}$

The Constitution currently in effect was enacted in 1982. ${ }^{3}$ Through a series of amendments constitutional principles such as rule of law, and protection of human

1 Building Constitutionalism in China, eds. S. Balme, Michael W. Dowdle, New York 2009, p. 112; D. Zolo, The Rule of Law: a Critical Reappraisal [in:] The Rule of Law History, Theory and Criticism, eds. P. Costa, D. Zolo, Dordrecht 2007, pp. 29-30.

2 Building Constitutionalism..., p. 115.

3 All references to the People's Republic of China constitution come from: Constitution of the People's Republic of China, http://www.npc.gov.cn/zgrdw/englishnpc/Constitution/ 
rights have been incorporated, and the Constitution is a relatively complete constitutional text. ${ }^{4}$ The Constitution of the People's Republic of China (hereinafter also as: Constitution) consists of an extensive preamble and 143 articles divided into four chapters: General principles (I), Fundamental rights and obligations of citizens (II), State structure (III), Flag, anthem, state emblem and capital (IV).

The extensive preamble of the Constitution of the PRC resembles important events in the history of the Chinese nation - achievements, figures, pointing them out as an example, and the achievements as a model to follow. The preamble contains elements of the tradition of the nation and the ideas, principles and values on which the state is based and indicates the goals of the nation and the state. China has been described as a country with one of the longest histories in the world. The participation of the nation in the struggles for independence, liberation, democracy and freedom as well as the Chinese revolutionary tradition was emphasized. In the preamble, it was pointed out that after 1840, China began the process of transformation into a semi-colonial and semi-feudal country. Then, the groundbreaking changes that took place in the $20^{\text {th }}$ century were pointed out. Introduction to the Constitution of the PRC resembles the revolution of 1911, which overthrew the feudal monarchy. However, it was claimed that the mission of the Chinese people, whose task is to overthrow feudalism and imperialism, continues. The preamble notes the changes that have occurred since the creation of the Republic of China, the transformation of a new democracy into a socialist society. The change in the form of ownership of the means of production that became state property was indicated, as wells as the establishment of a socialist system. The preamble generally indicates economic and cultural successes. It also contains the basic tasks of the nation for the future - building socialism with Chinese characteristics and socialist modernization. The five main ideologies that the Chinese nation should follow: Marxism-Leninism, Mao Zedong's thought, Deng Xiaoping's theory, the important thought of the three represents, and Xi Jinping Thought on Socialism with Chinese Characteristics for a New Era. ${ }^{5}$

Deng Xiaoping's theory refers to the four cardinal principles (四项基本原则, sì xiàng jīběn yuánzé), i.e. the political leadership of the Chinese Communist Party (hereinafter also as: CCP), the democratic dictatorship of the people as the basis of the state, the economic system in the form of a 'socialist road' and the guidance

node_2825.htm; http://www.fdi.gov.cn/1800000121_39_4866_0_7.html (accesed: 10.12.2019) and Amendment to the Constitution of the People's Republic of China (2018), http://www. fdi.gov.cn/1800000121_39_4866_0_7.html (accessed: 10.12.2019); Konstytucja Chińskiej Republiki Ludowej, trans. Wu Lan, M. Dargas, Gdańsk 2012.

4 In the sense that the document covers the basic contents known in Western constitution, i.e. the role, powers, and structure of different entities within a state, namely, the executive, the parliament or legislature, and the judiciary; as well as the basic rights of citizens.

5 http://www.gov.cn/guoqing/2018-03/22/content_5276318.htm (accessed: 18.01.2020). 
of Mao Zedong's ideology of Marxism, Leninism and thought. ${ }^{6}$ The important thought of the three represents (三个代表, sān gè dàibiǎo) means that the CCP must represent the most fundamental interests of the majority of the people. The three-represents theory means enabling active political life for those who represent: 1) developed production forces, 2) progressive forces involved in building a high culture, 3) the CCP represents the fundamental interests of the majority, which means seeking a consensus on political matters.

The theory of the three represents was presented in 2000 by Jiang Zemin as justification for the legitimization of the CCP as the ruling party. The most important element of this theory was the principle of representation of the 'fundamental interests of the majority of the nation.' According to this theory, the task of the party is to represent the needs of the leading production forces, the leading culture, the representation of the fundamental interests of the majority of the nation. ${ }^{7}$ On July 1, 2001 in his speech, Jiang Zemin stressed the need to adapt the MarxistLeninist doctrine to Chinese specifics. ${ }^{8}$ Hu Jintao - Chairman of the People's Republic of China in 2002-2012 and Secretary General of the CCP - presented during the XVII CCP Congress in 2007 explained that the theory of socialism with Chinese characteristics includes a system of scientific theories: Deng Xiaoping theory, important thought of three represents, scientific worldview for development and other strategic theories. The system of these theories represents the party's observance of the principles and development of Marxism-Leninism and the thoughts of Mao Zedong and embodies the wisdom and hard work of several generations of Chinese communists who have led and supported citizens in tireless discovery and practice. The last achievement is the adaptation of Marxism to Chinese conditions, the invaluable political and intellectual contribution of the party and the common ideological foundation of the efforts of people of all ethnic groups. ${ }^{9} \mathrm{Xi}$ Jinping, who has been the Chairman of the PRC since 2012, at the XVIII CCP Congress in 2012 referring to the socialism with Chinese characteristics, indicated that 'the socialist system of Chinese characteristics has become the fundamental achievement

6 Deng Xiaoping, 坚持四项基本原则 [The Four Cardinal Principles], 1979. http://cpc.people.com.cn/GB/69112/69113/69684/69695/4949681.html (accessed: 21.01.2020). Przestrzegać czterech podstawowych zasad (30 marca 1979) [in:] Chinska droga do socjalizmu. Wybór prac z.1956-1987, Deng Xiaoping, trans. Z. Góralczyk et al., Warszawa 1988, p. 106.

7 “Bejijing Review," http://bjreview.com.cn/17thCPC/txt/2007-10/content_79344.htm (accessed: 15.01.2020).

8 Jiang Zemin 在庆祝建党八十周年大会上的讲话 [The speech to National People's Congress, http://www.people.com.cn/GB/shizheng/16/20010702/501591.html (accessed: 10.01.2020).

$9 \mathrm{Hu}$ Jintao, 高举中国特色社会主义伟大旗帜为夺取全国建设小康社会新胜利而奋斗 [Holding the banner of Chinese socialism and striving for new victories in building a moderately prosperous society] [in:] 七大报告辅导读本 [Report from the $17^{\text {th }}$ Congress of the CCP], Beijing 2013, p. 11. 
of our party and the nation achieved as a result of a relentless struggle, just like this has happened over the past 90 years and that we should value what has already been done, and try to continue and enrich our achievements. ${ }^{10}$

In the introduction to the Constitution of the PRC, the need to take action to unite China was also stressed. The Chinese People's Political Consultative Council was mentioned as an organization that plays a very important role in the socialist modernization and unification of the country. The preamble indicates that the PRC system is a system of multi-party cooperation and political consultation. It directly defines the leading role of the Chinese Communist Party. The preamble mentions equality, unity and reciprocity as the basis of socialist relations. The independent position of China in the international arena was also determined and the principles of respecting sovereignty and territorial integrity, mutual non-aggression, mutual non-interference in internal affairs, equality and reciprocity of benefits and peaceful development of diplomatic, economic and cultural relations with other countries. The last paragraph of the preamble points to the overriding role of the Constitution of the PRC in the system of sources of law. ${ }^{11}$

Chapter one of the Constitution of the People's Republic of China (hereinafter also as: PRC) in articles 1-32 contains the general principles of the Chinese legal order. The People's Republic of China was defined as a socialist state under democratic dictatorship led by the working class and based on the alliance of workers and peasants. The defining feature of socialism with Chinese characteristics is the leadership of the Communist Party of China The People's Republic of China governs the country according to law and makes it a socialist country under rule of law (article 1 and article 5). ${ }^{12}$ All power in the People's Republic of China belongs to the people. The National People's Congress and the local people's congresses at various levels are the organs through which the people exercise state power (article 2), whose members are elected by elections. The PRC state organs implement the principle of democratic centralism (article 3). Article 4 of the Constitution of the PRC states that all ethnic groups living in the PRC are equal, and the state supports areas inhabited by minority ethnic groups. The Constitution provides possibility of implementing regional autonomy by particular ethnic groups (article 4).

The basis of the socialist economic system of the People's Republic of China (article 15) is socialist public ownership of the means of production, namely, ownership by the whole people and collective ownership by the working people (article 6), and the state-owned economy is the leading force in the national economy (article 7). The Constitution allows functioning within the national economy:

\footnotetext{
10 Xi Jinping, Innowacyjne Chiny, trans. S. Szafarz, Warszawa 2015, p. 26.

11 The Preamble to the Constitution of PRC.

12 Wording after the latest amendment from March 11, 2018, http://www.npc.gov.cn/wxzl/ gongbao/node_4366.htm (accessed: 15.01.2020).
} 
rural collective economic organizations (article 8), individual and private sectors of the economy (article 11), state-owned enterprises (article 16), collective economic organizations (article 17), foreign enterprises and other economic organizations or individuals (article 18). Public property in accordance with the Constitution of the PRC is 'sacred and inviolable' (article 12). All land in cities (article 10) and all mineral resources are owned by the state (article 9). Rural and suburban land, not owned by the state, is owned by collectives. Individuals or economic organizations may be given the right to use certain land (article 10). The state protects the private property of its citizens. However, it is permissible to expropriate or acquire property. In such case, the citizen is entitled to compensation (article 13).

The duties of the state include the development of education (article 19), support for scientific development and dissemination of scientific knowledge (article 20 ), development of medical services (article 21), promotion and support for cultural development (article 22), staff training (article 23), building a socialist spiritual civilization (article 24), promoting family planning in accordance with the social and economic development of the country (article 25), protecting and improving the living conditions of the people (article 26). The state organs in the performance of tasks are guided by the principle of simple and effective administration and have the obligation to carry out the will of the people (article 27).

The Constitution of the PRC requires the state to maintain public order and ensure security (article 28). National armed forces of the PRC are appointed for national defense (article 29).

The Constitution defines the administrative division of the country. According to article 30 of the PRC Constitution, the country is divided into provinces, autonomous regions, and directly governed municipalities. The Constitution provides the possibility of creating, if necessary, special administrative regions whose system is defined by the laws enacted by the National People's Congress (article 31).

The Constitution also provides the obligation to care for the rights and interests of foreigners who reside within the territory of China, and foreigners who apply for asylum for political reasons may obtain it (article 32).

The second chapter of the Constitution of the PRC defines the basic rights and duties of citizens, such as equal justice under law (article 33), passive and active electoral rights (article 34), freedom of speech, press, assembly, association, and demonstration (article 35), freedom of religion (article 36), personal freedom (article 37), personal dignity (article 38), inviolability of residence (article 39), freedom and privacy of correspondence (article 40), right to criticism and suggestion in relation to state authorities, to make complaints, allegations and denunciations on the actions of state organs or officers, the right to compensation for damages incurred in connection with the activities of state authorities (article 41), the right to financial aid by the state (article 44, 45), the right to receive education (article 46), the freedom to conduct scientific research, literary and artistic work and other cultural activities (article 47). 
The Constitution of the PRC also grants the right to work (article 42) and rest (article 43), workers' right to a pension (article 44), the right to gender equality (article 48), the right to protection of marriage, family, mother and child (article 49), the right to protection of rights and interests Chinese citizens staying abroad and the rights and interests of Chinese citizens returning from abroad and family members of Chinese citizens living abroad (article 50), foreigners have the right to asylum for political reasons (article 32), defendants have the right to defense (article 130), the right to protect the rights and interests of foreign enterprises, foreign economic organizations, joint ventures with Chinese and foreign capital domiciled in China (article 18).

All persons holding the nationality of the PRC are citizens of the PRC. Every citizen has the rights and duties set out in the Constitution of the PRC and laws (article 33). Citizens of the People's Republic of China, exercising their freedoms and rights, may not violate the interests of the state, society and the collective or legal rights and freedoms of other citizens (article 51). Citizens have the right to social security (article 45).

Chapter III of the Constitution of the PRC defines the structure of state bodies. Section 1 of Chapter III states that the highest body of state power is the $\mathrm{Na}$ tional People's Congress (hereinafter also as: NPC) whose deputies are elected by the provincial congresses. The Constitution provides a four-level power structure (article 95). At the highest level there is the central government, provinces (including the directly governed municipalities and ethnic autonomous areas), cities and counties, municipal districts and districts within cities.

In the last, fourth chapter of the Constitution of the People's Republic of China in three articles, the appearance of the state flag (article 136) and state emblem (article 137) was determined, the March of Volunteers is the anthem of the People's Republic of China (article 136) and the capital of the country is Beijing (article 138).

II. Latest amendments - the significance and effects of the amendments to the Constitution of March 11, 2018. ${ }^{13}$

After introducing the thought of $\mathrm{Xi}$ Jinping as one of the foundations of Chinese state ideology, the theories of President Xi became the official doctrine of PRC, and the president of the PRC became the first leader since the time of Mao Zedong, whose ideas were included in the constitution during the life of their author. Since the latest amendment to the Constitution, the Chinese authorities have been seeking to spread Xi Jinping's theory to Chinese citizens. Xi concepts are also a separate academic subject at Chinese universities. Many Chinese universities have introduced a subject or course on Xi Jinping's thought. No other Chinese leader other than Mao Zedong has had such strong promotion in the scientific community.

\footnotetext{
13 The detailed analysis of the amendment from March 11, 2018 can be found in: M. Dargas-Draganik, Chiński konstytucjonalizm - najnowsze zmiany w Konstytucij Chińskiej Republiki Ludowej, “Gdańskie Studia Azji Wschodniej” 2018, z. 14, pp. 53-69.
} 
$\mathrm{Xi}$ Jinping's concepts relate to the following issues: 1) socialism with Chinese characteristics, 2) implementation of the 'Chinese dream' - the revival of the Chinese people, 3) comprehensive and in-depth reforms, 4) economic development, 5) rule of law, 6) China culturally advanced, 7) social enterprises, 8) progress in the field of ecology, 9) national defense, 10) 'one country, two systems,' 11) peaceful development, 12) a new model of relations between the major powers, 13) diplomatic relations with neighbors, 14) cooperation with developing countries, 15) multilateral relations, 16) close ties with society, 17) fight against corruption, 18) the managerial role of the CCP. ${ }^{14}$

It should be noted that the wording added in the latest amendment regarding 'Chinese socialism for a new era', ecology, the rebirth of the Chinese nation, and harmony are part of the thoughts expressed by Xi Jinping. Amendments to the Constitution confirm the philosophy of scientific development and the guiding of socialist ideology with Chinese characteristics in national politics and social life in the era of $\mathrm{Xi}$ Jinping. Other changes in the preamble are a consequence of indicating Xi Jinping's thoughts as the basis of state ideology. ${ }^{15}$

Sentence added in article 1 of the Constitution, 'The leadership of Chinese Communist Party is the defining feature of Chinese socialism' is the legitimacy of the Party's power. Until now, the reference to the leadership of the Communist Party of China was only in the Preamble to the Constitution, the nature of which is the subject of in-depth scientific discourse. The Party's power was constitutionalized for the first time. ${ }^{16}$

Until now, the administrative power of the people was represented by state organs. The political power of the nation as a whole was expressed through the CCP. The representative nature of the CCP in Chinese constitutionalism proceeded in two directions. It obliged the CCP to abide the normative framework of the organization of political life expressed in the Constitution of the PRC itself. The CCP also served as the supreme executor of the political principles upon which the state is based, exercising de facto actual power in the PRC. Structures ensuring this fidelity were an important topic of constitutional debate..$^{17} \mathrm{~A}$ solution has been sought for a long time to legitimize the CCP's power and formally place it in the Chinese constitutional order. The change sanctioned the CCP's leadership as the only political force that counts in China.

The amended Constitution also included the obligation for state officials to publicly take a constitutional oath after taking office. The purpose of this change is to

14 Ibidem, p. 67.

15 Ibidem.

${ }_{16}$ More detailed analysis on legitimization of CCP power in: M. Dargas, Idee i zasady konstytucyjne chińskiego porzadku prawnego, Warszawa 2017, pp. 302-311.

17 Ibidem, p. 309. 
educate and motivate officials to be loyal to the Constitution, observe, respect and protect the authority of the Constitution.

In addition, a paragraph about the local legislative authority has been added. The possibility of issuing local regulations to cities divided into districts was granted. The provision regarding the need to approve regulations by the permanent committees of local people's congresses of the provinces or autonomous regions aims to prevent the dispersion of regulations and the creation of so-called reproduction law.

The granting of constitutional status to supervisory committees and the establishment of the State Supervisory Commission is also of great importance. This change sanctions the reform of the supervisory system. These changes are aimed at enabling cooperation between state institutions for anti-corruption activities and strengthening the CCP's centralized leadership in anti-corruption activities. The Supervisory Committee is created by and is accountable to the National People's Congress. The term of office of the chairman of the State Supervisory Commission is the same as the term of NPC and may not exceed two consecutive terms. The State Supervisory Commission is the highest supervisory body that manages the work of the supervision committee at all levels, and the higher-level supervision committee manages the work of the subordinate supervision committee. The State Supervisory Commission is dedicated to prosecute the abuse of employees of state institutions (approx. 200 million people). ${ }^{18}$

One of the most important changes in the current Constitution is the abolition of the term of office of the President and Vice-President of the People's Republic of China, which means that Xi Jinping will be able to rule for life, and if not, at least until he chooses his successor. The justification for this change was to provide the possibility of long-term management of the country and long-term stability of power in the Party and the country. It should be noted that in the Constitution of the PRC in the wording of 1982, the term of office of the President of the PRC was introduced to avoid concentration of full power in the hands of one man. Such a provision in the Constitution was a very important postulate of Deng Xiaoping (leader of China in 1978-1989). The reason was events related to the dictatorial management of the state by Mao Zedong, who exercised absolute power. In this regard, Deng's postulate was that instead of fully belonging to one man, power should be treated collectively, while ensuring constant fluidity in the exchange of political personnel. This system functioned efficiently (excluding the transfer of power in 2002-2004). The amendment to the PRC Constitution, which abolishes the term of office, again allows one person to exercise all power.

It should be noted that a very important change from the point of view of Chinese constitutionalism is the change in article 70 of the Constitution. In the second paragraph, the NPC Standing Committee (hereinafter also as: NPCSC) was

18 M. Dargas-Draganik, Chinski konstytucjonalizm..., p. 68. 
changed to the Constitutional and Legal Committee. This signals that this Committee may be given powers of constitutional review and interpretation.

The constitutional changes introduced on March 11, 2018 were the first changes in the PRC constitution in 14 years. A number of momentous amendments have been introduced that deal with issues that have long been appearing in scientific and political debate in both China and the West. The most commented change was the abolition of the term of office of the President of the PRC, however, from the point of view of the development of constitutionalism in China, the most momentous change will most likely prove to be enabling the Constitutional Committee and Legal Constitutional control and interpretation of the provisions of the Constitution of the PRC. A change of great significance from the point of view of the Chinese constitutional order is also the constitutional legitimacy of the CCP's power. Time will show how in practice these changes will influence the emerging Chinese constitutionalism. ${ }^{19}$

\section{The development of Chinese constitutionalism}

\section{First constitutional case}

The Qi Yuling case (2001) was actually a civil case involving the defendant's misappropriation of the plaintiff's name. Having passed the provincional entrance examination for specialized vocational schools the plaintiff Qi Yuling was admitted to Jining Commercial School in Shandong Province. Yet the admission letter for Qi was picked up by her classmate, Chen Xiaoqi, who then enrolled in the Jining School under Qi's name. Upon graduation Chen then took a job under Qi's name and worked for ten years before her false identity was discovered by Qi Yuling herself. Qi then brought a lawsuit in the Intermediate People's Court of Zaozhuang in Shandong province claiming misappropriation of her identity and violation of her right to education. The trial court awarded her RMB 35,000 for Chen's misappropriation of her name but declined to provide remedy for the violation of her right to education, claiming that she had waived the right by subsequent actions.

Qi Yuling then appealed that decision to the High People's Court of Shandong Province arguing that her subsequent actions could not be construed as waiving her civil-law right to education. Because of the complexities of the case, the Hight Court filed an inquiry to the Supreme People's Court seeking direction. According to the High Court that the plaintiff's 'right to education' was a constitutional right under article 46 of the PRC constitution and that as a constitutional right it could not be waived.

19 Ibidem, p. 69. 
This was the first time that a Chinese court had ever cited a constitutional provision in issuing a judicial interpretation. ${ }^{20}$

\section{Mechanism for reviewing violations of the constitution}

In 1982-2003 there was a legal regulation in China regarding the supervision and repatriation of tramps and beggars in cities, which defined the administrative procedure according to which the police could have detained a non-resident citizen or a temporary residence permit and return to a place where he could legally live or work (usually this concerned rural areas), defined also the requirement to have valid identity card.

In March 2003, 27-year-old Sun Zhigang, a Hubei provincial, was detained by the police in front of an Internet café in Guangzhou. Although he was a legal resident in Guangzhou, he did not yet have a provisional residence permit and did not carry his ID. In connection with this, he was arrested because of the suspicion that he is an illegal immigrant. The detention lasted all night, then Sun was transported to a repatriate institution. A few days after the detention, the clinic cooperating with the institution where Sun was placed informed that he died of heart problems. The official autopsy revealed by the deceased's family showed that Sun was beaten 72 hours before his death, with no external signs of beating. The family of the deceased reported the case to investigative reporters at the Southern Metropolitan, a daily newspaper published in Guangzhou, who published information on Sun's incident and death on April 25, 2003, indicating that he was improperly arrested and beaten during his detention, resulting in his death. Report on the death of Sun immediately raised public opinion, which expressing its indignation has put pressure on the authorities investigating this case. In May 2003, local authorities announced that Sun had been improperly detained and therefore had appropriate consequences for those responsible for the course of events - suspects were arrested - eight patients of the facility and five employees of the medical clinic were detained. In July 2003, a trial was held and all suspects were sentenced from 3 years of imprisonment until the death penalty. In addition, six public security staff responsible for stopping Sun were charged and convicted and sentenced from 2 to 3 years of imprisonment.

On the basis of the case of Sun Zhigang, three lawyers: Xu Zhiyong, Teng Biao and Yu Jiang referred to NPC SC, pursuant to article 90 section 2 of the legislative act, proposals for changes in the regulations concerning bukou (hereinafter referred to as: Proposal) questioning their constitutionality. The lawyers in the application pointed out: "we express concern about the system as such. A mechanism should be established to control violations of the Constitution in order to eliminate and

${ }^{20}$ Kui Shen, Is It the Beginning of the Era of the Rule of the Constitution? Reinterpreting China's First Constitutional Case, "Pacific Rim Law and Policy Journal" 2003, no. 12, p. 199. 
prevent such violations." They pointed out two main issues. Firstly, they pointed out that the regulation concerning the hukou system was adopted in violation of article 8 and article 9 of the legislative act. As the second argument, they indicated a violation of article 37 of the Constitution, according to which the personal freedom of citizens of the People's Republic of China is inviolable. No citizen may be arrested without the consent of the People's Public Prosecutor's Office or the decision of the People's Court, and the arrest must be carried out by a public security authority. Unlawful deprivation or restriction of the personal liberty of citizens by detention or in any other way is prohibited, and unlawful personal review of citizens is prohibited. ${ }^{21}$

Some commentators in this case pointed out that the hukou regulation formally violated article 37 of the Constitution, because it was adopted in breach of the procedure set out in article 8 and article 9 of the legislative act. Other commentators have pointed out that the regulation, by its very nature, violates article 37 of the Constitution. The authors of the Proposal themselves did not indicate which interpretation they were pursuing. In order to publicize the matter, the authors of the Proposal published an article on this subject in 'China Youth Daily.22

On 22 May 2003, another five lawyers sent a petition to NPC to amend the hukou regulation. At the end of May, NPC announced that it accepted both documents and analyzed them. On June 18, 2003, the State Council announced that Prime Minister Wen Jiabao had approved a new regulation regarding residence and residence permits, which would replace the old regulation.

The effect of the Sun Zhigang case was that by quickly changing the hukou rules by the State Council (the new regulation was largely a repetition of previous regulations), the NPC constitutionally blocked the constitutionality of the old regulation, which would be a breakthrough in Chinese constitutionalism. It was pointed out that OZPL's failure to exercise its right to control constitutionality meant that the whole matter related to the Proposal lost its rank and did not affect the development of the rule of law. The effect of bringing the opinion and publicizing the whole matter was the appearance of further civic proposals addressed to Standing Committee of NPC.

The case of Sun Zhigang created a precedent for a proposal for constitutional review. In the long run, the Sun case initiated the citizens' use of the right to submit proposals to NPC Standing Committee. The fact that NPC SC formally accepted the proposal constituted an enormous step in the development of Chinese constitutionalism, initiated discussions on the appropriateness of establishing an

21 M. Dargas, Idee $i$ zasady ..., p. 313, and sources there indicated.

22 Cui Li，三公民上述人大建议对手㭉办法进行危险审查 [Three Chinese citizens appealed to NPC, proposing constitutional review of the surveillance and repatriation system], 中国青年报,“China Youth Daily,” 16.05.2003. 
appropriate institution and creating appropriate procedures that would allow the consideration of such proposals. In addition, it drew public attention to the issues of constitutional control and contributed to the increase of constructive consciousness of Chinese citizens. In June 2004, NPC SC announced that an appropriate unit was set up to check the legal incompatibility of individual acts and consider proposals from citizens. In December 2005, NPC SC took subsequent steps, adopting appropriate regulations defining the procedure for controlling administrative regulations and interpretation of judges. The case of Sun Zhigang created an opportunity to raise the question of the status of the Constitution and the protection of its provisions. This case became a catalyst for constitutional activism. The basis for constitutional review is article 90 section 2 of the legislative act of the PRC, which states: 'when public authorities (...) public institutions, enterprises and other institutions or citizens believe that administrative regulations, local laws, autonomous regulations or other provisions are inconsistent with the Constitution or statutes, they may submit written proposal for their inspection to the Standing Committee of the National People's Congress, and the Standing Committee will consider the proposals and, if necessary, forward them to the appropriate special commissions for their consideration and suggestion. ${ }^{23}$ The legislative act, in article 90 introduces citizens' right to demand that the NPC SC review the constitutionality or legal compliance of administrative acts or local regulations, even if they do not relate directly to it. Article 90 of the PRC legislative act stipulates that the State Council, the Central Military Commission, the Supreme People's Court, the Supreme People's Prosecutor's Office, the NPC SC committee and permanent committees of local people's assemblies may request in writing the NPC SC to investigate whether an administrative regulation or local regulations are compliant with the Constitution and laws. The right to control the constitutionality of legal norms has been granted to NPC SC, which, pursuant to art. 67 section 1 of the Constitution has competence to interpret the Constitution and supervise its implementation. ${ }^{24}$

\section{Constitutionality of the provisions regarding demolition}

On December 23, 2009, when a demolition group arrived in the supposedly illegal construction of Tang Fuzhen and her husband in the city of Chengdu (capital of the Sichuan province), a tragedy similar to the tragedy in Sun Zhigang case was

23 Legislation Law of the People's Republic of China Adopted at the third Session of the Ninth National People's Congress on March 15, 2000 and promulgated by Order No. 31 of the President of the People's Republic of China on March 15, 2000), http://www.npc.gov.cn/ englishnpc/Law/2007-12/11/content_1383554.htm (accessed: 12.01.2020).

24 K.J. Hand, Citizens engage the Constitution [in:] Building Constitutionalism..., p. 230. 
repeated. After an unsuccessful attempt to prevent the demolition, shielding the building with her own body, Tang spilled oil on herself and set herself on fire. Despite her immediate help, she died in the hospital a few days later. The information spread immediately on the internet together with a video recording made by a neighbor using a mobile phone that clearly recorded the scene of self-immolation. As with Sun Zhigang case, information about the event had a huge impact on society. Five law professors from the Beijing University approached the OZPL Standing Committee with a request to examine the constitutionality of the provisions regarding demolition. Although the house of Tang Fuzhen was in fact an illegal construction, this fact turned out to be irrelevant to the public, and public pressure to repeal the provisions on demolition procedures was enormous. The Legal Commission of the State Council reacted immediately - on the same day as the scholars made their request. After several meetings with law professors invited to express their opinions, a draft amendment to the old regulation was abolished, in which many constitutional violations were eliminated, but the adoption of the final version took a very long time due to different regulations on local governments' revenues. Unlike the repatriation regulation, the amendment of the demolition regulation was a much more difficult task because it encountered serious resistance from local governments that were deprived of a significant proportion of their tax revenues. The regulation was not amended until January $21,2011 . .^{25}$

4. Recent developments regarding reviewing regulations facilitations of the access to the procedure of reviewing regulations

On December 4, 2019 the NPCSC officially launched a new online platform for citizens, legal persons, and other organizations to submit requests for review. Previously, they must mail their suggestions to the LAC's Office for Recording and Reviewing Regulations (法规备案审查室, făguì bèi’àn shènchá sbì).

The NPCSC may review the legality or constitutionality of six types of legal documents: 1) administrative regulations (行政法规, xingzhèng făguī);2) local regulations (地方性法规, difäng xing fágui); 3) autonomous regulations (自治条例, zizhi tiáolì); 4) separate regulations (单行条例, dänxing tiáoli); 5) special economic zone (SEZ) regulations (经济特区法规, jingì tèqü făguì); 6) judicial interpretations (司法 解释, sifă jiěshi).

25 Yan Jun, Chen Haiting King, China: Understanding the Regulations on Expropriation and Compensation of Housing on State-owned Land, http://www.mondaq.com/x/155158/Building+Construction/ Understanding + the + Regulations + on + Expropriation + and + Compensation + of + Housing + on + Stateowned+Land (accessed: 10.01.2020). 
5. The case of phone search provisions - revision of local regulations

In 2017 using cell phones while driving was one of the main causes of traffic accidents in China. Between 2012 and mid-2017, distracted driving caused about 11\% of all traffic accidents that led to civil lawsuits. Enforcement is lacking, however, because distracted driving is relatively hard to detect (despite China's ubiquitous surveillance cameras). To combat this problem, several provinces passed 'phonesearch provisions': regulations that allow the police to inspect the communication records of motorists involved in accidents. Those records could provide the definitive proof of whether a driver was using cell phone just before an accident, helping the police determine the liability of each party. The NPCSC Legislative Affairs Commission (LAC) decided in 2019 that the phone-search provisions 'implicate the citizens' freedom and privacy of correspondence and have no basis in [national] law' and has asked the provinces to 'correct' their rules.

Although the LAC's decision has not been made public, it has an important constitutional dimension because of the expansive view of the constitutional 'freedom and privacy of correspondence.' The decision may also be the result of the LAC's first-ever constitutional review under the Legislation Law. ${ }^{26}$

\section{The future of constitutional review}

Liang Ying, director of the Office for Recording and Reviewing Regulations under the Legislative Affairs Commission of the NPCSC, revealed that authorities are now contemplating significant expansion of the scope of constitutional review, following the Chinese Communist Party's decision to 'advance constitutional review' at its $19^{\text {th }}$ Congress. ${ }^{27}$ Liang stated that constitutional review is currently one of the two categories within record and review. Both constitutional review and report and review procedure seek 'to ensure strict enforcement of the Party Central Committee's and the Central Government's decisions, to ensure the correct and effective implementation of the Constitution and laws, to safeguard the authority and sanctity of the Constitution and laws, and to protect the people's lawful rights and interest. ${ }^{28}$

26 Changhao Wei, Recording \& Review Pt. 5: "Freedom and Privacy of Correspondence", https:// npcobserver.com/2019/06/10/recording-review-pt-5-freedom-and-privacy-of-correspondence/ (accessed: 25.01.2020).

27 Interview with Liang Ying, http://www.legaldaily.com.cn/rdlf/content/2018-01/16/content_ 7449400.htm?node=33048 (accessed: 27.01.2020).

28 Ibidem. 
Liang presented four mechanisms for constitutional review. Firstly, constitutionality consultation: a mechanism by which the enacting organ of a normative document during drafting, asks 'the relevant organ' for an advisory opinion on whether the document or its particular provisions are constitutional. Secondly, ex ante review: a mechanism by which 'the relevant organ' conducts constitutional review of a normative document after it has been adopted but before it is promulgated and enters into force. Thirdly, ex post review: a mechanism by which state organs, citizens, or social groups submit requests for review if they consider that a normative document violates the Constitution (the 'constitutional review' portion of the current record and review system, perhaps without the 'recording' requirement). Fourthly, finding 'support and basis' in the Constitution for the Party's and the State's major decisions. ${ }^{29}$

It is possible that a new specialized constitutional review body would be established under the NPC. Liang suggests that establishing a constitutional review system occupies a high position in the Party's 'law-based governance' program.

According to Liang, constitutional review will operate 'within the framework of the people's congress system,' the NPC(SC) will retain their power to supervise enforcement of the Constitution. Nevertheless, it is highly improbable that Supreme People's Court or any specialized constitutional court will be given the power of constitutional review. But the courts could be empowered to screen requests for constitutional review and refer meritorious ones to the NPC(SC). ${ }^{30}$

\section{Conclusion: Chinese Constitution and Chinese constitutionalism}

The Constitution of the People's Republic of China may be defined as a normative act that gives the legal system a framework, as a political act, as an ideological act, but above all as one of the elements of the Chinese constitutional order, of which the Constitution of the CCP is also a part.

These three systems - political, economic and social - function as an integral whole in the great practice of building socialism with Chinese characteristics and this is a clear feature of the CCP's long-term efforts to build socialism.

In the Chinese law, the influence of various Western systems is noticeable. However, at present, it is not possible to distinguish which of China's legal systems drew the most. Unfortunately, foreign legal solutions were accepted with little understanding of the context. Until recently, before the adoption of a provision, it was

${ }^{29}$ Changhao Wei, NPCSC Now Researching Expansion of Constitutional Review, https://npcobserver.com/2018/01/26/npcsc-now-researching-expansion-of-constitutional-review/ (accessed: 28.01.2020).

30 Ibidem. 
not examined whether there are local conditions or local resources enabling the application of foreign law. However, the recent actions of the authorities are promising, because before the adoption of the regulations, research on the so-called local conditions. This is related to the concept of creating a harmonious society.

Building a framework for understanding both the structure of Chinese constitutionalism and its legitimacy is associated with the problem of communitarian society in the Chinese legal system. This requires the positioning of law in a structure in which relations between law, politics and state are reversed - in a system in which sovereign powers constitute an incarnation of the masses and are divided between administration and politics, law has administrative functions and is limited by the limits of the jurisdiction of the state apparatus. In such a constellation, the creation of a constitutional norm and its development loses its character of law and assumes the role of the normative basis of political will. Constitutional law is understood as separate from the law necessary for the administration of the state to preserve the order of the nation, and the role of the lawyer is shaped by this dual nature of the law. The administrative nature of the law is connected with the fact that lawyers deal with it and it is consistent with the doctrine of Marxism because of the limitations of social relations. The function of law is to manage these relations, which limit freedom in the sense of a discreet environment and, through the main principles, ensure correct relations with others. Relationships are not organic and natural, and therefore can be managed through instruments such as the law for specific purposes. At the administrative level, the relationship between law as a tool of management and law as the personification of social consensus is more comprehensive, and excessive instrumentalization can reduce productivity. ${ }^{31}$

Chinese constitutionalists understand this at a certain level, but increasingly treat failure of the implementation of the constitution as systemic failure of the Chinese constitutional order. The essence of Chinese constitutionalism is its approach to the separation of administrative power (implemented in the form of traditional law - state) from political power (jointly exercised by the institutional representation of the sovereign political power - the CCP). This is a unique Chinese approach to democratic principles implemented by an institutionalized and representative body of political power, which is open to all citizens wishing to take over basic normative duties, maintains and maintains the responsibility of governmental apparatus set up to oversee. The effort to deepen constitutional development consists in a careful examination of the constitutional scope of weaknesses and the legality of the constitutional order. It seems important to discuss the forms in which democracy is to be developed in China, the important consequences of the division of power between politics and administration and the rejection of the western model of division of

31 M. Dargas, Idee i zasady ..., pp. 328-330. 
powers (between executive, legislative and judiciary) and the adoption of a division of power in which administration and politics are connected.

Despite the deviation from the constitutional court activism in the Qi Yuling case (2001), progress in Chinese constitutionalism is continuing. Subsequent civil initiatives initiated by the proposal to control the constitutionality of the hukou case initiated by the Sun Zhigang case (2003) point to the increasing constitutional awareness of Chinese society. From the case of Sun Zhigang to the Tang Fuzhen case (2009), and recent cases, i.e. cell phone case from 2019. Chinese constitutionalism has evolved, although this is happening very much slow pace. It turns out that the position of public opinion in particular matters is not without significance. Highlighting violations of law, including violations of the Constitution, widespread discussions on this subject, have an impact on the activities of state bodies. Considering the role of citizens' activity in the PRC, one can speak about the formation of popular constitutionalism. It should be noted that this popular constitutionalism may pose many threats if the Chinese authorities do not introduce appropriate procedures and are subject to pressure from the public. If the public will be able to influence the decisions of formally independent bodies, then popular constitutionalism may lead to regress in the constitutional process of the Chinese legal order.

The basic problem in China is not legislation, but the implementation of the law. The recent changes seem to have a positive impact on building the constitutionalism in China.

\title{
STRESZCZENIE
}

\author{
ROZWÓJ KONSTYTUCJONALIZMU \\ W CHIŃSKIEJ REPUBLICE LUDOWEJ
}

W artykule przedstawiono podstawowe informacje na temat treści chińskiej konstytucji i rozwoju chińskiego konstytucjonalizmu. Omówiono najbardziej reprezentatywne przypadki, które wskazują ewolucję chińskiego konstytucjonalizmu i konieczność kontroli konstytucyjnej. Wydaje się, że starania przewodniczącego Xi Jinpinga dotyczące skupienia się na stosowaniu i implementacji postanowień konstytucji mają pozytywny wpływ na chiński konstytucjonalizm. 